\title{
Lacuna in the Legal Regime to Curb Air Pollution in India
}

\author{
Vishal Bera* \\ ${ }^{*}$ Corresponding Author \\ Vishal Bera

\section{Article History} \\ Received: 14.07.2019 \\ Accepted: 25.07.2019 \\ Published: 30.07 .2019
}

Advocate, Calcutta High Court, BBA.LL.B (Hons.), IMS Unison University, LL.M. (CAL), Christ University, Hosur Main Road, Bhavani Nagar, S.G. Palya, Bengaluru, Karnataka 560029, India

\begin{abstract}
Once again the latest uproar over the toxic concentrations of pollution in the Country's National Capital Region has brought to light the inability of India's Legislative and Legal processes to regulate the increasing air pollution. Despite the early Legislative Recognitions of Air Pollution problem and the parallel establishment of regulatory processes, India is unable to limit the sharp upward trajectory of air pollution. While several problems regarding the country's legal and regulatory system governing air quality deserves severe and urgent consideration, this article focuses in specific on one problem i.e. the liability system for infringement of air quality norms. This article is broken down into three streams. The first segment describes the appropriate law provisions relating to liability for causing air pollution either Civil or Criminal. The Second aspect discusses three critical problems emerging under the present responsive system: (1) The pollution control boards have no authority to impose penalties; (2) The prosecution of criminal offenses is not an effective solution; and (3) There is no full relief provided by the National Green Tribunal Act. The article's third and final portion suggests a way forward. It is suggested that extra enforcement powers should be given to the Pollution Control Boards, and administrative penalties should be implemented for violations, albeit under certain circumstances.
\end{abstract}

Keywords: Lacuna, Air Pollution, Infringement, Penalties, Legislature, Liability

\section{INTRODUCTION}

The most contemporary and debatable topic in India is about the rise in level of air pollution through the emission of toxic elements and with the Country's capital reaching its highest level bringing into notice the failure of regulations and the legal regime in India to curb and regulate Air pollution. According to the report released by the World Health Organization in 2014, out of the top 20 cities of the world 13 are Indian Cities ${ }^{1}$. For the past 10 years India has been facing the grunt of air pollution as the air quality of the air index has worsened creating a matter of serious concern and due this the state and the Central Government are been able to contain the issue. In various ways the government not only has tried to curb the instances of serious pollution, but has vigorously granted pollution to rise in a fast rate by allowing the industries to pollute, by not taking preventive measures for vehicular pollution control and industrial pollution and by senselessly allowing increase in construction business and diesel generators.

The need to counter the problem of Air Pollution came in the manner of legislative development around 30 years ago when the "Air Act", Air (Prevention and Control of Pollution) Act 1981 was approved by the Parliament. This development in aspect of Air Pollution control has not been effectively implicated by the regulatory machinery as there is steeprise in air pollution in India. The first amendment to this act was made in the year 1987 and then again in the year 2010 which was limited to introduce the National Green Tribunal as a court of appeal, the Act has remained stagnant during the period and with its main clauses not being able to protect the nature and the rise in pollution in the country in the present decade.

With numerous laches and lacuna the legal framework and the regulatory machinery controlling the quality of air in the country counter grave and quick commendation as it focuses towards the legal liability regime towards the violation of right to healthy and pollution free environment and the violation of standard Air Quality Index. The context of the legal regime in context to air pollution

1World Health Organisation, Ambient (outdoor) air pollution in cities database 2014, available at http://www.who.int/phe/health_topics/outdoorair/databases/cities/en/ (last visited 16 June 2015).

Copyright @ 2019: This is an open-access article distributed under the terms of the Creative Commons Attribution license which permits unrestricted use, distribution, and reproduction in any medium for non commercial use (NonCommercial, or CC-BY-NC) provided the original author and source are credited. 
is further discussed through various statutory laws engrossing both criminal and civil liability through the Indian Penal Code and the Code of Criminal Procedure under the Criminal Liability part and National Green Tribunal Act 2010 and the Code of Civil procedure under the Civil Liability. However the above concept does not clarify the legal jurisprudence of the fundamental rights-based approach that has emerged from the prior decisions of the Apex court and the High Courts which has recognized Right to Healthy and Pollution free environment (air) in India [2]. The remedy of Constitutional Writ is a remedy available but cannot stand the limitations of the provided statutory provisions. The remedy itself available turns out to be discriminatory and the judicial courts are mainly ruthless to accept such cases if the available alternate remedy has not been exhausted contained under other statutory or legal provisions.

\section{DEFICIENCIES UNDERLYING TOWARDS THE LEGAL REGIME}

The Preamble of the Air Act enumerates that, the legislation was approved to implement the decisions adopted at the United Nations Conference on the Human Environment 1972 [3] participated by India [4]. It was decided during the Conference that the countries need to take preventive measures to conserve the nature and the environment which includes the controlling of air pollution [5] and maintaining the Air Quality Index. The various functions of the Central Pollution Control Board (CPCB) [6] are delineated in the Air Act as well as it includes the State Pollution Control Board (SPCB) [7]. The various functions of the concerned boards include issues concerning preventing and controlling air pollution, execution and planning for control and prevention and listing for Air Quality.

It is essential to indicate that prescribed standards for vehicular pollution and emission are projected and the intergovernmental committees with the help of participating industrial groups which is headed by the Joint Secretary and Ministry of Road transport and Highways [8]. It is the sole responsibility of the Ministry to implement the Motor Vehicles Act 1989 under which the canons are dispensed and imposed, the SPCBs and the CPCBs in tune with the Ministry for Environment, Forest and Climate change have only a small role to conduct in context to the vehicular emission regulations.

With reference to Section 21 of the Air Act, an industrial plant [9], without the consent of the State Pollution Control board cannot be set up for the purpose of operating or establishing such plan. The consent related to the above provision is called as Consent to Operate and the Consent to Establish. Under the Water (Prevention and Control of Pollution) Act 1984, known as the Water Act [10]. A Consent to Establish has to be obtained by the industrial plant before the beginning of the construction work. After the establishment of the plant the consent to establish has to be in tune to the pollution control system, then only the industrial plant may further apply for a Consent to Operate before the plant operation begins [11]. The power to propose the application process is with the State Government which includes the application fees and the necessary particulars details required [ ${ }^{12}$ ]. To consider an Consent Application the State Pollution Control Board such conduct an inquiry and shall duly follow the procedure established by the concerned State Government [ $\left.{ }^{13}\right]$.

The State Pollution Control Board has to necessitate a decision on the application in a period for four months in regards to the consent and shall initiate an order in written with specified reasons [ $\left.{ }^{14}\right]$. The Board has the power of refusal or may approve the same by issuing it with certain conditions (which includes the specification of the pollution control machineries and equipment) [15]. The consents granted by the board are for a specific period of time and as the time period gets expired it is subjected to renewal before the

2See Subhash Kumar v. State of Bihar (1991) 1 SCC 420; followed in M.C. Mehta v. Union of India (Aravalli Mining case) (2004) 12 SCC 118.

3 Declaration of the United Nations Conference on the Human Environment, 5-16 June 1972, UN Doc. A/Conf.48/14/rev1.

4 The Air (Prevention and Control of Pollution) Act 1981 ['the Air Act'], preamble.

5 Id.

6 The Air Act, s. 16.

7 The Air Act, s. 17.

8 See, Gaurav Bansal and Anup Bandivadekar, OVERVIEW OF INDIA'S VEHICLE EMISSIONS CONTROL PROGRAM: PAST

SUCCESSES AND FUTURE PROSPECTS 35 (International Council on Clean Transportation 2013).

${ }^{9}$ See, The Air Act, s. 2(k). See, Delhi Pollution Control Committee v. Splendor Landbase Limited, LPA 895/2010, Judgment of the High Court of Delhi dated 23 January 2012. The High Court considered the definition of an 'industrial plant'. It held that 'the inevitable conclusion has to be that prior consent under the Air Act would be needed where a building is proposed to be constructed wherefrom trade would be carried on and since from a shopping mall and from a commercial shopping complex trade is carried on, we hold that prior consent under the Air Act would be required'.

10 The Water (Prevention and Control of Pollution) Act 1984 ['the Water Act'], s. 25.

${ }^{11}$ See, Himachal Pradesh State Pollution Control Board, Office Procedure Manual, 6-7, available at http://hppcb.nic.in/OfficeManual.pdf (last visited: 16 June 2015).

12 The Air Act, s. 54(2)(I).

13 The Air Act, s. 54(2)(m).

14 The Air Act, s. 21(4). Interestingly, the consent granting provision under the Water Act includes a deeming provision that the Air Act does not have. Section 25(7) of the Water Act, states that a consent will be deemed to be given after the expiration of four months in case the SPCB has not decided the consent application.

$15 \mathrm{ld}$.

(c) South Asian Research Publication, Bangladesh

Journal Homepage: www.sarpublication.com/sariaf 
board. The consent provided by the SPCB may be rejected before the expiration of the time period or refusal of the consent to renew may be given if it is found that conditions which are laid down are not in compliance with the given consent [ $\left.{ }^{16}\right]$. In case of a technological advancement or any other improvement the SPCB may resort to revision of the conditions laid down in the consent [17]. Subsequently in such matters a reasonable opportunity has to be given to the concerned individual for the right to be heard before the decision of the SPCB [18].

The order notified by the SPCB can be challenged by the aggrieved party before the Appellate Authority set up by the State Government [19]. The Supreme Court of India by an order of 1999 iterated that the, Appellate Authority shall be presided by a sitting or a retired High Court Judge, and high ranking group of scientists having vast experience for adjudicating disputes related to pollution and environment [ $\left.{ }^{20}\right]$. The phrase "aggrieved person" has been interpreted in such a manner that that it includes not only persons but also the ones who have filed application for the consent and also those who want to contest the rejected consent application or the conditions imposed upon the consent in cases but includes persons affected by the consent granted towards the industrial plants and any other person who are to be affected by the emission and pollution discharge by the industrial units [ ${ }^{21}$. Any petition which are subject to appeal before the appellate body duly established under this statute cannot be pleaded before the Civil Court [22]. The National Green Tribunal has the power to hear appeal against the order or decision of the Appellate Authority [ $\left.{ }^{23}\right]$.

The Air Act of 1981 provides a stability and regulation for commanding and controlling the subject matter with the help of criminal legislation. Section 22 of the Air Act, prevents the industrial bodies from discharging any air pollutants which is in excess of the standards as prescribed by the SPCB through exercising its power as stated in Section 17(1)(g) of the Act. The State Pollution Control Board can approach a Court but not subordinate to Judicial Magistrate of the First Class or Metropolitan Magistrate for restricting any individual likely to cause air pollution [24]. The Act also authorizes the SPCBs to gather evidence about discharge of pollution from industrial plants, inspect and enter premise, take samples of release and direct for examination [ $\left.{ }^{25}\right]$.

In case of excess emission of the permissible standard which have taken place or likely to have been occurred due to an unanticipated event, the individual in charge of the plant has been positioned under an responsibility to notify the State Pollution Board immediately $\left[{ }^{26}\right]$. Any corrective measures undertaken by the SPCB or any other authority to alleviate the effect of such emission of air pollutants is recoverable from the concerned person [ $\left.{ }^{27}\right]$. The above provision covertly recognizes and institutes the polluter pay principle; this principle finds a place in the National Green Tribunal Act 2010. The Section also establishes the Absolute Liability Principle which was inserted to the Indian Environmental Legislation by the Apex Court of India through the Oleum Gas Leak case [ ${ }^{28}$ ] the landmark decision in 1987.

The SPCBs and CPCBs are given additional powers to grant certain instruction to ensure amenability with the provisions of the legislation through an amendment in 1987 [29]. The above provision includes direction for regulation or prohibition, closure of any

\footnotetext{
16 The Air Act, s. 21(4), first proviso.

17 The Air Act, s. 21(6).

18 The Air Act, s. 21(4), first proviso and s. 21(6).

19 The Air Act, s. 31.
}

${ }^{20}$ A.P. Pollution Control Board v. Prof. MV Nayudu (1999) 2 SCC 718, para 48; see also, Puducherry Environment Protection

Association v. The Union of India, WP No. 19496/2013, Judgment of the High Court of Madras dated 11 April 2014.

21 See Gujarat Pollution Control Board v. Parmar Devusinh Shersinh, Special Civil Application No. 11/1989, Judgment of the High

Court of Gujarat dated 5 May 2000, in the context of analogous appeals under the Water Act. See also, Vimal Bhai \& Others v.

Ministry of Environment and Forests \& Others, Appeal No. 5/2011, Order of the National Green Tribunal dated 14 December 2011.

22 The Air Act, s. 46.

23 The National Green Tribunal Act ['the NGT Act'], s. 16(f).

24 The Air Act, s. 22A(1).

25 The Air Act, ss. 24, 25 and 26.

26 The Air Act, s. 23.

27 The Air Act, s. 23(3).

28 M.C. Mehta v. Union of India (Oleum Gas leak case) (1987) 1 SCC 395. The Supreme Court in this case held (para 31):

"... an enterprise which is engaged in a hazardous or inherently dangerous industry which poses a potential threat to the health and safety of the persons working in the factory and residing in the surrounding areas owes an absolute and non-delegable duty to the community to ensure that no harm results to anyone on account of hazardous or inherently dangerous nature of the activity which it has undertaken. The enterprise must be held to be under an obligation to provide that the hazardous or inherently dangerous activity in which it is engaged must be conducted with the highest standards of safety and if any harm results on account of such activity, the enterprise must be absolutely liable to compensate for such harm and it should be no answer to the enterprise to say that it had taken all reasonable care and that the harm occurred without any negligence on its part."

29 The Air Act, s. 31A. 
industry, process or operation; or blockage or regulation of supply of water, electricity or any other service [ ${ }^{30}$ ]. Such directions are issued to individual who are guaranteed to comply with them [31]. Any appeal against the direction of the SPCBs and CPCBs will lie before the Appellate Body [ ${ }^{32}$ ] and any appeal against the order or judgement of the Appellate Body will lie before the National Green Tribunal [33].

Failure to comply, by any individual, under Section 21 or Section 22 or directions under Section $31 \mathrm{~A}$, penalty can be imposed under Section 37 of the Air Act. Where a industrial plant is commenced or established for the purpose of operation without obtaining necessary consent would fall under the category of failure to compliance, prior violation of the conditions laid down in consent has been committed, for example the permitted emission standard has been exceeded or requisite pollution control machinery has not been installed. If such failure is observed then the person shall be imprisoned not less than one and a half years which may also extend up to 6 years along with fine [ ${ }^{34}$. If the failure is repeatable then extra fine may be imposed which may extend up to Rs.5000 for each day from the conviction of first offence. If the failure is continued for a period more than 1 year after the conviction date, the offender shall be punished with imprisonment for not less than two years, but extendable up to 7 years including fine [35]. Section 38 of the Act provides penalty for offences for providing false information for obtaining consent from state pollution central board; a person authorized by board is obstructed from discharging his duties; any property or work of the board is damaged, penalty is imposed upon such activities. Any of the above offence would draw an offence leading to imprisonment for a term extendable up to 3 months or a fine to the tune of Rs 10,000 or both. If any provision of the Act is contravened for which a penalty is not specified under Section 37 or 38, then the same is punishable with term for imprisonment extendable up to 3 months with fine or both [ ${ }^{36}$. In case the contravention of the statutory provision continues an additional fine shall be applicable [37]. The penalties mentioned above cannot be imposed by the SPCBs but shall be levied by a court of law. The concerned State Pollution Control Board Officer has to file the criminal prosecution through filing a complaint against the offence alleged, in the court not subordinate to a Judicial Magistrate First Class or of a Metropolitan Magistrate [ ${ }^{38}$. An Amendment was introduced in the year 1987 for increasing public cooperation for the purpose of implementing the law, an complaint other than the SPCB can also be filed by an person, but such person has to issue a notice before 60 days to the SPCB stating the intention for approaching the court [ ${ }^{39}$ ]. In the above matter it is the obligation of the SPCB to provide all required reports in its control to the complainant, by law $\left[{ }^{40}\right]$.

Moreover moving from the provision of the Air Act, any instances of Air Pollution can be prosecuted under IPC and cognizance can be taken through CrPC [ ${ }^{41}$. The offence of Public Nuisance is defined under Section 268 of the Indian Penal code [ $\left.{ }^{42}\right]$ and activities leading to air pollution can be practically be brought under the jurisdictional ambit of Section 268 . Any voluntary activity making the atmosphere noxious to breathe and harming human health is an offence punishable with a fine under Section 278 of the

$30 \mathrm{Id}$, explanation. While discussing the ambit of closure directions, the High Court of Delhi in Gopi Nath Pvt. Ltd. v. Department of Environment Govt. of N.C.T. of Delhi (1998) 72 DLT 536 held:

"Closing down all industrial activity is neither the purpose nor the object of the Act. Prevention of pollution is. If one particular component is the cause of pollution, the Board may well, subject to the provisions of the Act, direct its closure but it cannot seal the entire unit bringing thereby even unoffending activities to a standstill."

31 The Air Act, s. 31A.

32 The Air Act, s. 31. Although the provision does not specifically refer to directions issued under s. 31A, it is presumed that 'order' in s.

31 covers such directions.

33 The NGT Act, s. 16(f).

34 The Air Act, s. 37(1). It may be noted that the amount of fine is not specified in the Air Act. However, Section 29 of the Code of Criminal Procedure 1973 provides that a Judicial Magistrate First Class or a Metropolitan Magistrate can impose fines up to ten thousand rupees.

35 The Air Act, s. 37(2).

36 The Air Act, s. 39.

37 ld.

38 The Air Act, s. 43(1). See P. Pramila v. State of Karnataka, 2015 SCC OnLine SC 348. In this case the complaint was filed by the Regional Officer under s. 37 of the Air Act. The Supreme Court set aside the complaint as it was not filed by the competent authority under the Act. The Court held:

"The "officer authorised in this behalf" was not authorised by the provisions of Section 43 of the Air Act, or by any other provision thereof, to further delegate, the authority to file complaints. The Chairman of the Board, therefore, had no authority to delegate the power to file complaints, to any other authority, for taking cognizance of offences under the Air Act."

39 The Air Act, 43(1)(b).

40 The Air Act, 43(2).

41 See generally, P. Leelakrishnan, ENVIRONMENTAL LAW IN INDIA, ch. 2 (Lexis Nexis, 3rd ed 2008, Reprint 2013).

42 268. Public nuisance: A person is guilty of a public nuisance who does any act or is guilty of an illegal omission which causes any common injury, danger or annoyance to the public or to the people in general who dwell or occupy property in the vicinity, or which must necessarily cause injury, obstruction, danger or annoyance to persons who may have occasion to use any public right. A common nuisance is not excused on the ground that it causes some convenience or advantage.

Sections 290 and 291 of the IPC stipulate the punishment for the offence of public nuisance. 
IPC [ ${ }^{43}$. Smoking in public is an offence under Section 278 of the IPC as iterated by the Kerala High Court in its 1999 Judgement [ $\left.{ }^{44}\right]$. The offences specified under Section 279 and 269 are both bailable and non-cognizable offences attracting a penalty of Rs.500 and with the possibility of a lengthy trial, prosecutions under these sections are not likely to prevent polluters.

Under Section 133 of the Criminal Procedure Code an action can be instituted against any person for committing any particular act which is injurious public health or causes physical discomfort to the society. Air pollutants emitted by the industrial plant or the processing units thereby causing severe health hazards to the citizen residing nearby can also be served notice by the Magistrate under this section for preventing such activities of pollution. In the case of Kachrulal Bhagirath Agrawa v. State of Maharashtra [45], the Supreme Court upheld an direction under Section 133 of the Crpc for stopping the storage and transporting dry chillies from a storage as it was creating Public Nuisance by creating all sorts of pollution and discomforts to the citizens living in the surrounding areas. The Court iterated that:

"Section 133 is applicable in cases of Public Nuisance. The Magistrate performs its public duty by serving the members of the public who are subject to public nuisance and the same shall be exercised if the jurisdictional facts call for. The conduct of such public nuisance shall be must be injurious to the health of the society at large. There shall be presence of imminent danger to the public and its surrounding where the industry or the trade is located or carrying on its mode of operation."

The Air Act, Indian Penal Code and the Criminal Procedure Code covers the area for criminal prosecution in case of air pollution and the matters of Civil Suit is proceeded by the National Green Tribunal in any event of Air Pollution. The substantial question related to the environment which include enforcing of legal rights related to the environment is covered under the Original Jurisdiction of National Green tribunal [46]. Such questions have arose from the implemented 7 laws listed under the Schedule of the National Green Tribunal which includes the Air Act $\left.{ }^{47}\right]$. In cases of direct violation of the statutory provision that impacts the society at large is matter of substantial question under the environment; the quantum of damage done to the environment is considerable or the damage done is broadly measured under the human health hazard or it can be proved through an application the environment is facing the consequences due to a particular activity and pointing towards the pollutant $\left.{ }^{48}\right]$.

The victims of the pollution can be granted compensation and relief by the order of the Tribunal and the tribunal can also order for restoring the damaged environment of the location and the properties $\left[{ }^{49}\right]$. Compensation can be granted under the Schedule II of the NGT Act which includes injury, medical expense, disability, death, sickness, loss of wage, etc [50]. According to the Act, the person damaging the environment is held liable for dispensing the compensation as set out by the Tribunal [51]. The Tribunal applies the no fault principle in case of an accident [52] - as the absolute liability principle was followed in the case of Oleum Gas leak Case. The Tribunal has the power to apply the precautionary principle and sustainable development principle along with the Polluter Pay Principle for deciding cases [53]. Apart from the power of determining compensation the Tribunal has the power to grant interim orders which includes interim injunction or stay orders and orders requiring persons to terminate and discontinue from causing harm towards the environment54. The execution of a order of the Tribunal can be done as the decree of the Civil court and in regards to this it has all the powers of the civil court [55]. The Tribunal's order is appealable before the Supreme Court [56].

To tackle the menace of Air Pollution the Tribunal can use its powers by passing variety of orders. In a case of Environmental damage especially concerning air pollution in the region of Rohtang Pass, Himachal Pradesh, the Tribunal passed various orders which included restriction upon the numbers of cars passing each day, imposing payment for compensation towards the environment on each car and drawing a line between petrol and diesel vehicles and directing the state government to manage

\footnotetext{
43 278. Making atmosphere noxious to health.-Whoever voluntarily vitiates the atmosphere in any place so as to make it noxious to the health of persons in general dwelling or carrying on business in the neighbourhood or passing along a public way, shall be punished with fine which may extend to five hundred rupees.

44 K. Ramakrishnan v. State of Kerala, AIR 1999 Ker 385. The Court held:

"There can be no doubt that smoking in a public place will vitiate the atmosphere so as to make it noxious to the health of persons who happened to be there. Therefore, smoking in a public place is an offence punishable under Section 278, IPC."

45 (2005) 9 SCC 36.

46 The NGT Act, s. 14(1).

47 Schedule I of the NGT.

48 The NGT Act, s. 2(1)(m).

49 The NGT Act, s. 15.

50 Schedule II of the NGT.

51 The NGT Act, s.17.

52 The NGT Act, s. 17(3).

53 The NGT Act, s. 20.

54 The NGT Act, s. 19(3).

55 The NGT Act, s. 25.

56 The NGT Act, s. 22.
} 
congestion of traffic $\left[{ }^{57}\right]$. In response to the increasing Air Pollution in the NCR, the direction from the Tribunal was that 10 year old diesel vehicles and 15 year old petrol vehicle shall not be registered in the National Capital Region [ ${ }^{58}$. The Tribunal further also issued orders relating to reduction in pollution in the NCR caused from the construction activities [59]. The remedy for Public Nuisance is also given under the Civil Procedure Code and potentially it is a legal remedy for air pollution. In other civil suits, an injunction or appropriate remedy or a declaration may be asked for. In the above cases the individual filing the suit does not need to prove that the damage has been specially caused to them.

\section{THE ISSUES INVOLVING THE STRUCTURAL PROBLEM}

The Air Quality Index or the Air Quality Status in most of the Indian towns and cities showcase that the present legal regime is not properly established or implemented to strictly punish the offenders of Air Pollution or prevent future occurrence. The objective of the Act has not been achieved by the present model of legislation. To regulate the air pollution under the ambit of Air Act it has to be evenly moderated and numerous conditions have to be fulfilled. The enforcement of the law shall pose a threat to the violators and the legal sanction to be imposed in proportion to the damaged caused. Proper method of data collection to be carried out along with monitoring the capacity of the regulation committee has to be strong and shall be amenable to change standards and propose technical protocols in regards to the changing conditions of the environment. Information irregularities need to be reduced among the board. Provisions related to accountability and transparency should be tough enough to eradicate malpractice and corruption.

The underlying reasons due to which the above mentioned conditions are not met in a proper manner in India- political, legal, institutional, cultural, bureaucratic and financial- and all of them require an deep introspection. Out here we continuously focus on legal regime of the air pollution inclusive of its liability and it consists of three main areas which scoops into the proper functioning of the existing legal enforcement towards the environment.

\section{Adequate Penalties Cannot Be Levied By the Pollution Control Board}

The State Pollution Control Board and the Central Pollution Control Board are the two most effective institutional machineries of the Government to curb and maintain air pollution but both cannot or not authorized to impose penalty on the units or the industrial plants, as the sole power to impose penalty is with the Criminal Court. Both the boards also cannot institute the closure of an violating unit or plant and also cannot restrict power or water supply.

If closure of industrial plants is imposed it may check upon or curb pollution but instantly it will lead to grave problems such as unemployment, regulate a negative impact on the economic condition of the market products, will lead to wastage of raw materials purchased by the industrial bodies and both private and public bodies will bear the brunt of the closure. In the following matters the imposing of the direction shall not be in proportion to the event of violation. The concept of closure will solve no further purpose to the effect of air pollution caused in the environment nor it will be compensatory solution to the victims of the air pollution in the society. Such direction if called upon would need the coordination of the inter-agency for further effect. Therefore such solution shall not serve the adequate measure to resolve the problem of increasing air pollution.

Section $31 \mathrm{~A}$ of the Act is open in all directions, but the interpretation is done in regards to the exclusion of any direction for the purpose of imposing penalty, as the penal powers have been mentioned in the act. The Judicature of Delhi High Court has brought out the conditional grant of consent through penalty imposition or furnishing bank guarantee or fine and the Boards cannot direct payment towards damage done to the environment as it would lead to imposition of penalty [ $\left.{ }^{60}\right]$. The duty of board is then limited to issuing show cause notice and sending closure notice. The boards cannot stop the operation of the pollution units and may end sending disproportionate response.

\section{Criminal Prosecution Is Not the Effective Solution}

The conclusion of any case takes a long time in litigation before the court of law. The industrial unit continues to pollute the environment until a stay order is ordered by the court to prevent the unit from carrying out its operation during the lis pendens. A case related to environment goes through various courts and forums and each judicial or administrative body takes its own time for final adjudication. The same was highlighted in the matter of Uttar Pradesh Pollution Control Board v Mohan Meakins Ltd., where the Apex Court adjudicated a matter in context to river pollution after 17 years of prosecution of the State Pollution Control Board. Conclusion of a legal adjudication does not go well for accurate and timely pollution reduction. Just because of the time taking process of the litigation the conviction rate in such cases is low and it further deters the criminal prosecution impact.

\footnotetext{
57 See Court on its own Motion v. State of Himachal Pradesh, Application No. 237 (THC)/2015, before the National Green Tribunal, Principal Bench. See in particular Orders dated 6 February 2014 and 5 May 2015.

58 See Vardhaman Kaushik v. Union of India, Original Application No. 21/2014, Order dated 7 April 2015 of the National Green Tribunal, Principal Bench.

59 Order dated 4 December 2014 of the National Green Tribunal, Principal Bench.

60 See Splendor Landbase Ltd. v. Delhi Pollution Control Committee (2010) 173 DLT 52, upheld in Delhi Pollution Control Committee.
} 
The limited power of the Boards to adjudicate matters in a diligent manner has led to problem of conducting legal proceedings. As per reports it has been found that the SPCBs are not well resourced and financed 61 , and with the wide range of tasks to perform and undertake, they have to inescapably prioritize the use of natural resources. The process of granting consent takes up most of the resources and time of the SPCB leaving out nothing for the enforcement and the monitoring functionaries. With the burden of enough workload, less staff strength and less will of the politics, going to court for seeking conviction is not considerable in relation to the time and resources of the Board.

\section{Complete Relief Is Not Provided By the NGT Act}

The SPCB and CPCB having the road to approach the National Green Tribunal62, under Section 15 of the Act as an aggrieved party [ ${ }^{63}$ ] for restoration of the environmental damage and to claim compensation, is only a part addressing the problem. The Jurisdiction of the Tribunal over air pollution is limited to civil proceedings. Criminal Liability cannot be determined by the Tribunal and punishment leading to imprisonment or fine cannot be imposed upon. The matters of grievous pollution, or repeat in violation of the mentioned standards and/or sustaining inability in the view of pure evidence of impact upon environment, a civil suit for liability is not always sufficient to the response. If criminal prosecution would bring upon custody and damage to reputation and in some cases it would necessitate the offender to be punished and it would prevent activities of pollution in near future.

Apart from limited Jurisdiction, recourse to judicial action is not the perfect machinery for protecting the Air Quality index of the country or any other environmental damage or pollution. To control the effect of rising air pollution in India what is mostly required is the improved control of the institutional machinery and policies shall be initiated at both the state and central level in matters of transportation, industries, construction and there shall be cooperation between the private and public body for proper implementation. The above mentioned function are outside the jurisdiction of the Indian Judiciary inclusive of the National Green Tribunal. Undoubtedly the Indian Judiciary has played an vital role in governing the environment but the lacuna lies with inadequacy of the executive which remains barefaced about the progressive law. The Indian Judiciary does not have ample time to create policies in relation to environment that could look into the local, regional and national environmental issues, and then apparently monitor the implementation of the policies. The tribunals are in a better position for determining environmental problems and further implementing orders rather than the regular court of law. But the orders of the tribunals still remain challenging while venturing into policy making. The orders of the Tribunal raise eyebrows upon the effectiveness and enforceability of judicial orders [ ${ }^{64}$ ], and in also regards to the effective decision making process of the Judiciary [65].

\section{The Way Forward Towards An Adequate Solution}

The present legal machinery is not appropriate enough to tackle the rising air pollution in the Country of India and the same is about to increase in the future generation. This is evident enough to introduce a reformative reformation. In August 2014 the Government of India formed a High Level Committee to develop new reformative measures for the purpose of reviewing the Environmental Laws which includes the Air Act and suggesting amendments [ ${ }^{66}$ ]. The Committee only made observation on the purpose of checking vehicular pollution and the Report of the Committee did not give inclusive input towards the proper implementation of the Air Act. There will be enough advantage in bringing the Water and Air Act under the ambit of the amended Environment Act 1986. The present legal machinery is under very minute deliberation and the question which lies is that whether the amalgamation of laws would solve the very purpose of the Statute. The findings of the Committee were very appropriate which can be summarized below:

"All the Statutes under the revision of this committee failed the litmus test. The penal provisions either lack in some area or are not enough proportionate or sufficient enough to distribute the criminal justice system which is not properly aligned. The Committee notes the overdue operation of even the existing penal provisions, which is by itself a devastation."

\footnotetext{
${ }^{61}$ Centre for Science and Environment, TURNAROUND: REFORM AGENDA FOR INDIA'S ENVIRONMENTAL REGULATORS (New Delhi: Centre for Science and Environment, 2009), http://www.cseindia.org/sites/default/files/report.pdf (last visited: 17 June 2015); Geetanjoy Sahu, ENVIRONMENTAL REGULATORY AUTHORITIES IN INDIA: AN ASSESSMENT OF STATE POLLUTION CONTROL BOARDS (Mumbai, Centre for Science, Technology \& Society, School of Habitat Studies, Tata Institute of Social Sciences, 2013, available on file with author).

62 The NGT Act, ss. 14 and 15.

${ }^{63}$ The NGT Act, s. 2(1)(j)(viii) - person includes every artificial juridical person, not falling within any of the other sub-clauses.

64 See, Dinesh Mohan, Dealing with pollution in our cities, BUSINESS STANDARD, 4 April 2015, http://www.businessstandard.com/article/opinion/dinesh-mohan-dealing-with-pollution-in-our-cities-115040400713_1.html (last visited: 17 June 2015). 65 In the matter relating to air pollution in the Rohtang Pass region, the taxi operators union that was directly affected by the order of the National Green Tribunal, approached the Supreme Court, inter alia claiming that it was not heard by the Tribunal before the order was passed. The Supreme Court vide its order dated 26 May 2015 in Him Aanchal Taxi Operators Union v. State of Himachal Pradesh CA No. 4864/2015 directed the Union and other appellants to place before the Tribunal facts and issues which it had not considered before passing the impugned order. ${ }^{66}$ REPORT OF THE HIGH LEVEL COMMITTEE TO REVIEW VARIOUS ACTS ADMINISTERED BY THE MINISTRY OF ENVIRONMENT, FORESTS \& CLIMATE CHANGE (2014), http://www.moef.nic.in/sites/default/files/pressreleases/Final_Report_of_HLC.pdf (last visited: 3 June 2015).
} 
The governance of quality of air in India has to be radically improved in various ways. It is not a modest task to bring about a change in present legal mechanism. The law in question is about thirty years old which requires the Central and State Government to effectively function independently and coordinate with the various organizations. To control the various environmental defilements [ $\left.{ }^{67}\right]$ the governmental bodies consider imposing stronger penalties and introduce control mechanism to curb pollution [ ${ }^{68}$ ], and therefore the government has to introduce and accept a wide agenda to enhance the legal enforcement capabilities of the State Pollution Control Board because they are the first guardian of law in regards to the Environment. The maximum population of the country considers the National Green Tribunal as the prime Judicial Authority which is very undesirable and unfortunate for the Country. A legal regulatory mechanism which is competent and accountable enough to maintain the resources and is highly armored to implement the standards of the environment than the judiciary and is less corrupt in workforce and as additional human, financial and technical resources.

The SPCB has been granted more power to dispense the amended law along with the machinery to regulate the distribution of the policy and its instruments. Under the amended act the SPCB has the power to send notice and show cause the industrial plants and the unit and if the board is not satisfied with the response then it can order for closure of the unit and also can restrict the water and power supply. The SPCB has the power to cancel a consent and can also reject for renewing a consent. But the board cannot impose fine or damage in proportion to the environmental pollution created by the plant to institute immediate and urgent redressal methods. The power of the board needs to be collaborated with the power to levy fines, cancel bank guarantee and impose damages towards the environment which can easily facilitate the action to deter. The action of imposing financial penalty is precedented for causing environmental damage. In cases of hazardous waste management [69] the SPCB has the power to levy financial penalty. An option which has always remained opened is to resort to criminal prosecution but the same can be adopted in only a limited number of cases for example when other legal machinery fails to bring out the necessary result where the environment pollution is at the highest level.

There are two fold motives to provision the introduce the supplementary administrative powers. Firstly, supervisory diversity has been measured to be a superior alternative to a single strategy approach [70]. Power to impose administrative fines would give the SPCBs the necessary flexibility to customize their responses to environmentally harmful activities based on various (pre-determined) criteria. These criteria could be relevant policy goals, nature and gravity of offence, track record of defaulter, social and economic implications of alternative policy instruments, etc. To deal with the same regulated entity, the SPCB could adopt different policy instruments with escalating levels of severity depending on the entity's compliance behavior over time. Enforcement actions that are not as harsh as closure notices, and are quicker to implement than long drawn criminal prosecution, are likely to be imposed more often. If the probability of an enforcement action increases, regulated entities are more likely to be deterred from violating the law, thereby increasing the rate of regulatory compliance. One of the main reasons why the current criminal liability regime has failed is that the overwhelming pendency in the courts, and the procedural hurdles of proving a case beyond reasonable doubt negated any fear of penal action. Non-compliance does not come at a very high cost; and regulated entities are willing to take the (miniscule) risk. This tendency needs to be reversed.

Second, polluter pays principle is part of Indian environmental jurisprudence. The Supreme Court of India in several judgments has applied the principle to award damages [71]. Delayed and inadequate action (or no action at all) against polluting units violates this principle. The liability regime for air quality needs to reflect this cardinal principle of Indian environmental jurisprudence, and uphold the 'right to pollution free air'.

There have been some positive developments in empowering the SPCBs. The National Green Tribunal has upheld the power of the SPCBs to require the furnishing of bank guarantees as a condition in a consent and eventual revocation of such guarantees as compensation for environmental damage [72]. The Maharashtra State Pollution Control Board in its Enforcement Policy

\footnotetext{
${ }^{67}$ Amitabh Sinha and Liz Mathew, Tougher pollution laws soon, vows Environment Minister Prakash Javadekar, THE INDIAN EXPRESS, 5 May 2015, http://indianexpress.com/article/india/politics/tougher-pollution-laws-soon-vows-environment-ministerprakash-javadekar/99/ (last visited: 21 June 2015).

68 Vidya Venkat, Three months for fixing Delhi's pollution, THE HINDU, 14 April 2015,

http://www.thehindu.com/news/cities/Delhi/environment-ministry-announces-measures-to-address-delhis-air-

pollution/article7102033.ece (last visited: 21 June 2015).

69 The Hazardous Wastes (Management, Handling and Transboundary Movement) Rules 2008, r. 25(2).

70 Neil Gunningham and Darren Sinclair, Regulatory Pluralism: Designing Policy Mixes for Environmental Protection, 21(1) LAW AND POLICY 49 (1999).

71 Indian Council for Enviro-Legal Action v. Union of India and Others (Bicchri case) (1996) 3 SCC 212; and Sterlite Industries (India) Ltd v. Union of India and Others (2013) 4 SCC 575.

72 See, State Pollution Control Board, Odisha v. M/s Swastik Ispat Pvt. Ltd. \& Others, Appeal No. 68/2012, Order dated 9 January 2014 of the National Green Tribunal, Principal Bench. The Tribunal distinguished the case before it from the fact situation in the Delhi
} 
2014 has recognized the difficulties in securing compliance, and decided to implement a bank guarantee scheme, with the Board contemplating extreme measures (approaching a court of law or issuing closure licenses) only in five percent of the cases [73]. Furthermore, the High-level Committee reviewing environmental laws has suggested the promulgation of a new law - Environmental Laws (Management) Act 2014 - that, inter alia, encourages gradation of fines based on severity of offence $\left.{ }^{74}\right]$.

A note of caution may be recorded at this point. Any effort to empower the SPCBs must be accompanied by efforts to strengthen the SPCBs institutionally, make them financially independent and secure, and increase transparency in their functioning. Power to impose administrative fines etc. would only increase the width of discretionary powers that they currently enjoy. Efforts would have to be made to curtail the potential for abuse of these powers by putting in place appropriate monitoring and accountability mechanisms. While the modest reforms suggested in this essay are not without their own risks and costs, it is clear that maintaining the status quo is no longer an option.

Pollution Control Committee case, supra $\mathrm{n} 9$, by stating that an amount imposed as a compensation for environmental restoration was permissible, and that imposed as a penalty was not as only courts could impose any penalty under the Air Act.

73Maharashtra Pollution Control Board, Enforcement Policy,

http://mpcb.gov.in/images/pdf/Enforcement_Policy2014_legal.pdf (last visited: 21 June 2015).

74 REPORT OF THE HIGH LEVEL COMMITTEE, supra $\mathrm{n}$ 71, at 72 (Clause 8.2). 